\title{
Assessment of burrowing behavior of Procambarus clarkii, in Fatmia Drain, Sharqya Governorate, Egypt; Case Study Overview.
}

\author{
Magdy T. Khalil ${ }^{1}$, Mohammed R. Fishar ${ }^{2}$, Khadra A. Mohammed $^{3}$ \\ 1- Faculty of Science, Ain Shams University, Cairo, Egypt. \\ 2- National Institute of Oceanography and Fisheries, Egypt. \\ 3- National Water Research Center, Environment and Climate Research Institute, Egypt. \\ E. Mail:khokhacat@yahoo.com
}

\section{ABSTRACT}

The invasive Red swamp crayfish Procambarus clarkii was introduced in early 1980s into the Egyptian freshwater system for aquaculture from the United State of America. It has been, since, rapidly expended in all aquatic ecosystems including streams, ponds, and marshes; in polluted or clean waters. P. clarkii successfully adapted to Egyptian water streams and became an important component of the local aquatic fauna. It dispersed in fields and water canals through digging tunnels and burrows. Types of burrows and burrowing behavior of $P$. clarkii were assessed in Fatmia Drain in Dyarb-Negm, Zakazek Center, Sharkya Governorate, Egypt.

These burrows were recorded in many crops fields. Damage to levees structure and banks was depending on P. clarkii densities and its burrowing behavior. Each burrow entrance was represented by the earth "castle". The average number of burrows varied from 25 to 40 burrows $/ \mathrm{m}^{2}$ in poorly structured small channel banks of the study area. Burrowing behavior of $P$. clarkii triggered damage for levees and irrigation structures of small channels that forced the Ministry of Water Resources and Irrigation to periodical pitching those banks.

Keywords: Procambarus clarkii, burrows, Fatmia Drain, Egypt.

\section{INTRODUCTION}

The Cambaridae (Decapoda, Crustacea, Macrura) is the most diverse crawfish family with 12 genera and at least 360 species. Procambarus clarkii is one of the most abundant and commercial crustacean species all over the world (Huner, 1994). Crayfish are the largest mobile freshwater invertebrates and have been frequently recognized as key members of littoral food webs (Nyström, 1999; 2002). P. clarkii rapidly established self-sustaining populations and is now the most abundant crayfish species on the Iberian Peninsula.

Since the introduction of the red swamp crayfish $P$. clarkii in early 1980 s, into the Egyptian freshwater system for aquaculture from the United State of America, it has been rapidly expended in all aquatic ecosystems including streams, ponds, and marshes in polluted or clean waters. P. clarkii successfully adapted to the new habitats and became an important component of the local aquatic fauna (Rawi, 1995; Ibrahim et al., 1995; Tolba, 1999; Ibrahim et al., 2006).

The geographical distribution of $P$. clarkii in the Egyptian waters extends from the Giza Governorate in the south to the whole Delta region in the north, and to Qena Governorate in south (Ibrahim et al., 1995). In spite of the presence of P. clarkii in Sudan and Kenya (Huner, 1977), just south of Egypt, there is no clear evidence that it has migrated from Sudan to Egypt (Soliman et al., 1998b).

Soliman et al. (1998a) investigated the habitat and distribution of P. clarkii. They revealed that this species completely colonized mostly in Cairo, Giza and Delta 
waters. They described also the behavioral patterns of this species as a highly tolerant invader and usually founded in aerated, very shallow water such as marsh pools, ponds, irrigation canals and ditches. Also, $P$. clarkii is known to cause a lot of damage to the fisheries by damaging nets of fishermen and eating egg nests of fishes.

Soliman et al. (1998a) stated that $P$. clarkii is a bottom dweller and gut analysis showed that it is a veracious, indiscriminate and scavenger feeder. So, freshwater crawfish $P$. clarkii bio-accumulates heavy metals from its surrounding environments of sediments and water.

The most negative impact of the presence of $P$. clarkii in the Egyptian Nile waters, is its burrowing behavior. Their burrowing activities weaken small dykes; create leaks in levees and aquaculture ponds, and increases erosion along water courses, causing the water to flood the fields. Long-distance dispersal is facilitated by intentional introduction. On the local scale it can migrate long distances on land, even exceeding $3 \mathrm{~km}$ per day (Huner and Barr, 1991).

This study aimed to assess the impact of burrows of $P$. clarkii on Fatmia Drain network and its small channels in Dyarb-Negm, Sharkya Governorate, to provide further information for the comprehension of the invasive potentiality of this crayfish by underlining some aspects on its behavioral flexibility. This study area was selected due to suffering and continuous complaining of farmers from $P$. clarkii invasion in their fields causing damage for their crops and fields' levees.

\section{METHODOLOGY}

This study was conducted in Fatmia Drain network and its small channels in Dyarb-Negm, Sharkya Governorate, during summer 2007. External shapes, water levels of Procambarus clarkii' burrows were assessed using a photography camera captured photos in different small canals and crop fields. Photos were analyzed to measure the densities and count burrows' number in unit area in some small canals.

\section{RESULTS AND DISCUSSION}

All crawfish must live in wet areas, but some can adapt to temporary dry conditions. Most crawfish mature and immature burrow if the habitat dries up regardless of the time of the year. Thus, burrows play a vital part in the life cycle of the red crawfish; for spawning and reproduction. Perhaps the most impressive characteristics of the crawfish are their burrowing behavior and the earth "castles" that rise around each burrow's entrance. Holdich (2002) has provided an excellent description of the burrowing process and the categories of burrows built by various types of crawfish.

\section{Burrowing Behavior:}

The burrowing process of crawfish loosen the soil with its walking legs. As earth accumulates, the third maxillipeds are thrust below the lessened material. When they are loaded, the cheliped are pressed over the load and the crawfish moves head first through its burrow to the surface, where the compressed load, actually the pellet, is deposited and tapped into place with the claws. The crawfish then descends tail first, to repeat the process. Crawfish burrows are usually dug by an individual crawfish, with the burrow diameter determined by the size of the crawfish. The burrow extends downward into a terminal chamber that is slightly larger than the diameter of the tunnel (Gherardi, 2006). 
Crayfish burrows were found concentrated in small channels banks in wet and moist soil. Burrows chimney' texture were mainly soft clay. Maria et al. (2003) stated that Crayfish burrows were found concentrated around the water pools in wet or moist sediment. Burrows were made mainly of clay $(84.4 \%)$ and had an average water content of $(32 \%)$.

Hobbs et al. (1989) have suggested a unique function for these turret-like structures; it is possible that they function as ventilation system for the burrow and associated tunnel system (if present). Ventilation, except in time of drought, would make burrows more livable, as oxygen concentration in the water is normally very low. With respect to burrowing behavior, crawfish are divided to three categories; primary, secondary, and tertiary. Burrowing behavior is not restricted by genus, as representative species of several genera may share the same category. Most burrows are built at night and may require several days to complete (Hamdi, 1994)

Burrow entrances at the water's edge are often hidden under vegetation or woody debris. Over time, the burrow entrance may become undetectable because of weathering and vegetative growth. Burrows usually contain either a single female or a male and female. Occasionally, a burrow may contain a single male or more than two crawfish, Hobbs (1976).

The burrows morphology and density were described from different locations along Fatmia Drain. Burrows external morphology and densities were quite similar to that of El Zein (2005). The clay chimneys of $P$. clarkii burrows may be symmetrical or irregular, as in (Photo1). Water levels in burrows vary with the moisture conditions in the soil. Free water at the bottom of the burrow is more often associated with "trapped" water than the actual water table of the soil, as in (Photo2).

Damage to levees structure and banks is influenced by $P$. clarkii densities and its burrowing activities. The average number of burrows varied from 25 to 40 burrows per $\mathrm{m}^{2}$ in poorly structured small channel banks.

At Fatmia Drain, these burrows were recorded almost in most crop fields. However, Rice was ranked as the most dominant one of these crops (Photo 3), and this causes severe damage for the Rice crop (Photo 4). This is mainly due to that burrowing activity alters soil hydrology and causes water leakage.

The same results were recorded in Portugal (Fonseca et al., 1996) as the burrowing activity of $P$. clarkii increased the costs of rice production as they eat rice seedlings. Rice producers in Spain use pesticides to eradicate $P$. clarkii from their fields. Rice production is also damaged during the harvest of $P$. clarkii by harvesters. It is therefore thought that the majority of $P$. clarkii introductions in Spain had negative effects due to their burrowing ability (Gutierrez-Yurrita et al., 1999). Also, Hobbs et al. (1989) reported that, P. clarkii is especially considered a pest in agricultural areas, such as rice paddies, where it damages young rice plants as well as irrigation systems and dams.

\section{RECOMMENDATIONS:}

As the crayfish is an excellent source of food with a high protein content, popular in many parts of the world, we have to fish it in commercial quantities to decrease its negative impacts on levees and crop fields. This makes the crayfish a source for employment of young Egyptians .Further, the non-edible portion of the crayfish is an excellent source of protein and minerals for the feeding of animals, as chickens raised on a crayfish feed diet lay more eggs, and the eggs contained more protein (Ibrahim and Khalil, 2010). 


\section{REFERENCES}

El Zein, G. (2005). Introduction and impact of the crayfish Procambarus clarkii in the Egyptian Nile River. L'Astaciculteur de France, 84: 1-12.

Fonseca, J. C.; Marques, J.C. and Madeira, C.M. (1996). Oxygen uptake inhibition in Procambarus clarkii, red swamp crayfish, by bio-gradable surfactants: An ecotechnological approach for population control in rice fields. Freshwater Crayfish, 11:235-242.

Gherardi F. (2006). Crayfish invading Europe: the case study of Procambarus clarkii. Mar. Freshw. Behav. Physiol., 39, 175-191.

Gutierrez-Yurrita, P.; Martinez, J.M.; Bravo-Utrera, M.A. and Montes, C. (1999). The status of crayfish populations in Spain and Portugal. In: Gherardi F, Holdich DM (eds) Crayfish in Europe as Non-native Species - How to make the best of a bad situation?. Balkema, Rotterdam/Brookfield, pp 161-192.

Hamdi, S.A.H. (1994). Studies on the red swamp crayfish Procambarus clarkii (Girard, 1852) (Decapoda: Camrbaridae) in the River Nile, Egypt. M. Sc. Thesis, Cairo University, 154pp.

Hobbs, H.H. (1976). Crayfishes (Astacidae) of north and Middle America. In: Biota of freshwater ecosystems, identification manual. Water Poll. Res. Cont. Ser., Washington, D. C. 9: 1-173.

Hobbs H.H.; Jass J.P. and Huner J.V. (1989). A review of global crayfish introductions with particular emphasis on two North American species (Decapoda, Cambaridae). Crustaceana, 56(3): 299-316.

Holdich, D.M.; Ackefors, H.; Gherardi, F.; Rogers, D. and Skurdal, J. (1999). Native and alien crayfish in Europe: some conclusions. In: Ghrardi F, Holdich DM (eds) Cray- fish in Europe as alien species. How to make the best of a bad situation? Balkema, Rotterdam/Brookfield, pp 281-292.

Holdich, D.M. (2002). Biology of freshwater crayfish management and exploitation. Blackwell Press Oxford, U.K. 677 pp..

Huner, J.V. (1977). Introductions of the Louisiana red swamp crayfish, Procambarus clarkii (Girard): an update. Freshwater Crayfish, 3: 193-202.

Huner, J.V. and Barr, J.E. (1991). Red Swamp Crayfish: Biology and Exploitation. $3^{\text {rd }}$ Edition (Elizabith, B.C., ed.). The Louisiana Sea grant program, center for wetland resources, Louisiana St. Uni., Baton Rouge, Louisiana. 128 pp.

Huner, J.V. (1994). Ecological observations of red swamp crayfish Procambarus clarkii Girard, 1852), and White River crayfish, Procambarus zonangulus (Hobbs 1990), as regards their cultivation in eastern ponds. Freshwater crayfish, 10: 456-468.

Ibrahim, A. M. and Khalil, M. T. (2009). Freshwater crayfish in Egypt. Center of Res. \& Stud. of Natur. Protec., Ain Shams University, Egypt.

Ibrahim, A.M.; Khalil, M.T. and Mobarak, M.F. (1995). On the feeding behavior of the exotic Procambarus clarkii in Egypt and its prospects in the bio-control of local vector snails. J. Union. Arab Biol., Cairo. Zool. 4 (A): 1110-5372.

Ibrahim, A.M.; Emam, W.M.; Fakhry, F.M.; Rifai, A. and Abdel-Rahman, A.S. (2006). Toxicity and bioaccumulation of some heavy metals in the crayfish Procambarus clarkii in the River Nile, Egypt. J. Egypt. Acad. Soc. Environ. Develop., (D-Environmetal Studies). 7(2): 131-158. 
Mariam, I.; Patrizia, A.; Chiara, B. and Francesca, G. (2003). Shelter use of the RedSwamp Crayfish (Procambarus clarkii) in dry-season stream pools. E. Schweizerbart'sche Verlagsbuchhandlung, D-70176 Stuttgart.

Nyström P. (2002). Ecology. In: Holdich D.M. (ed.), Biology of Freshwater Crayfish, Blackwell Scientific Press, Oxford, 192-224.

Rawi, M.S. (1995). Toxicological and physiological characteristics of Aluminum in some freshwater mollusks and crustaceans. Proc. Zool. Soc. A. R. Egypt, 24: 224-243.

Soliman, G.N.; El-Assal, F.; Salah El-Deen, M. and Hamdy, S.A.H. (1998a). Habitat, distribution and behavior of Procambarus clarkii (Girard, 1852) (Decapoda: Cambaridae) in the River Nile, Egypt. Egypt. J. Zool., 30: 297-310.

Soliman, G.N.; El-Assal, F.; Salah El-Deen, M. and Hamdy, S.A.H. (1998b). The reproductive biology of the red swamp crayfish Procambarus clarkii (Girard, 1852) (Decapoda: Camparidae) in the River Nile, Egypt. Egypt. J. Zool., 30: 311-325.

Souty-Grosset C., Holdich D.M., Noel P.Y., Reynolds J.D. and Haffner P. (eds.), (2006). Atlas of Crayfish in Europe. Museum national d'Histoirenaturelle, Paris, Patrimoinesnaturels. pp. 64- 187.

Tolba, M.R. (1999). The red swamp crayfish Procambarus clarkii (Decapoda: Cambaridae) as bio-indicator for total water quality including $\mathrm{Cu}$ and $\mathrm{Pb}$ pollution. Egypt. J. Aquat. Biol. Fish. 3(1): 59-71. 

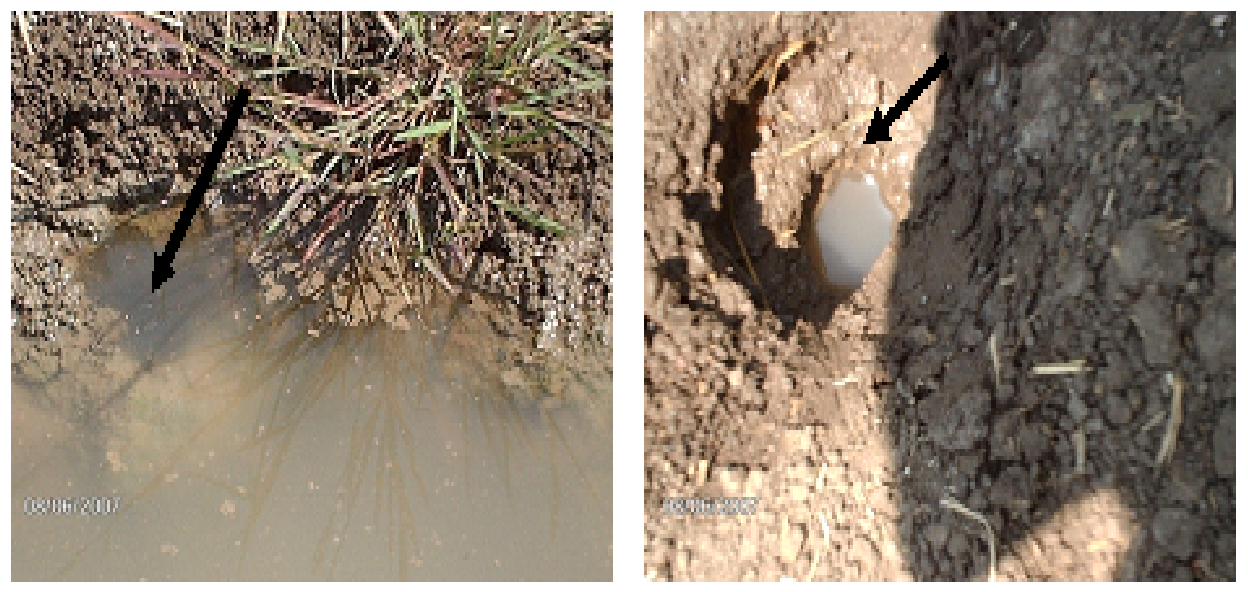

Photo 1: The chimneys of $P$. clarkii burrows; (a) irregular, (b) symmetrical at Fatmia Drain in Sharqya Governorate.

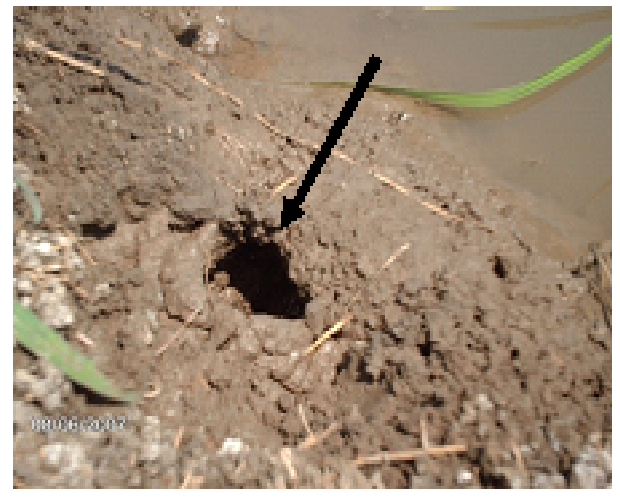

(a)

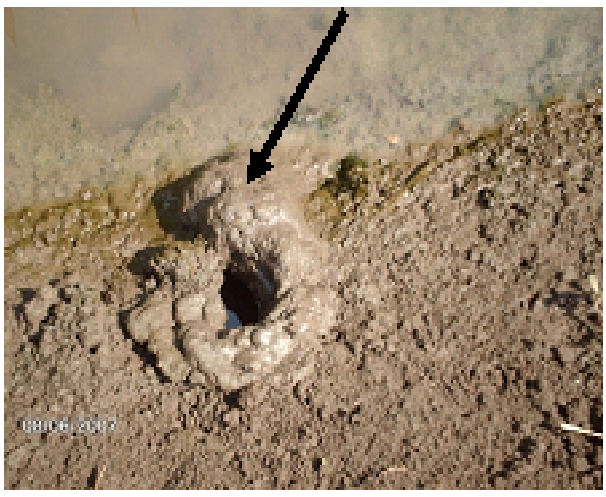

(b)

Photo 2: Water trapped at the bottom of P. clarkii burrows at Fatmia Drain
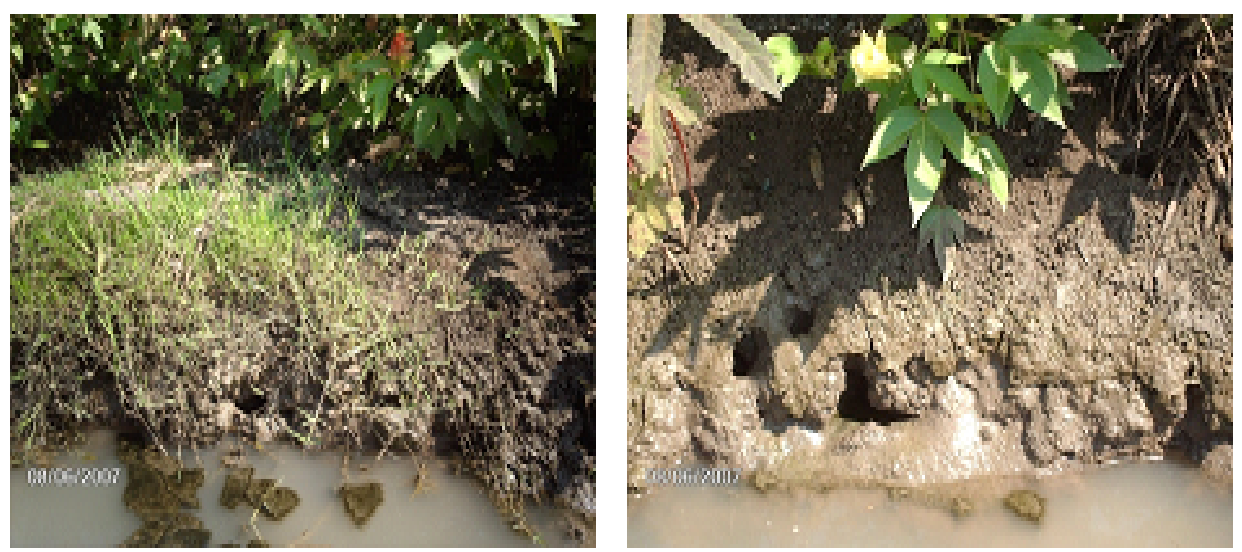

Photo 3: P. clarkii burrows densities at Fatmia Drain in Sharqya Governorate. 

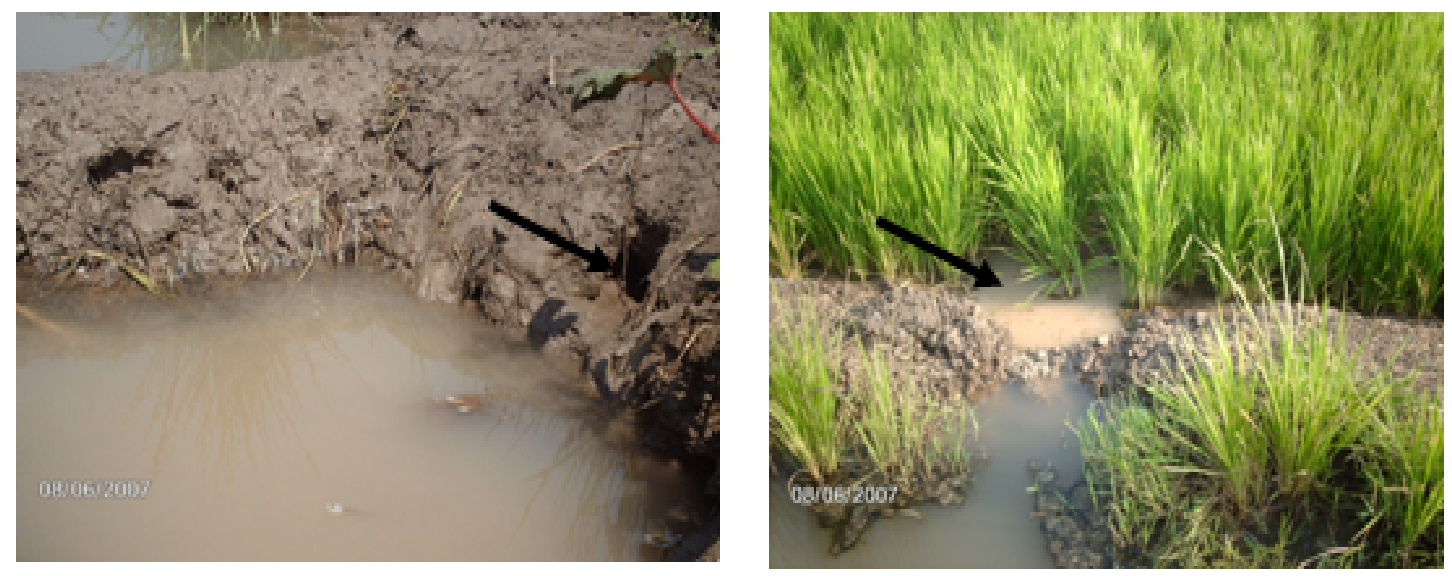

Photo 4: Damage of dykes and Rice crop in small irrigation channels at Fatmia Drain

Sharqya Governorate constructed pitching at Fatmia Drain to protect it from damages of crayfish burrows (Photo 5).
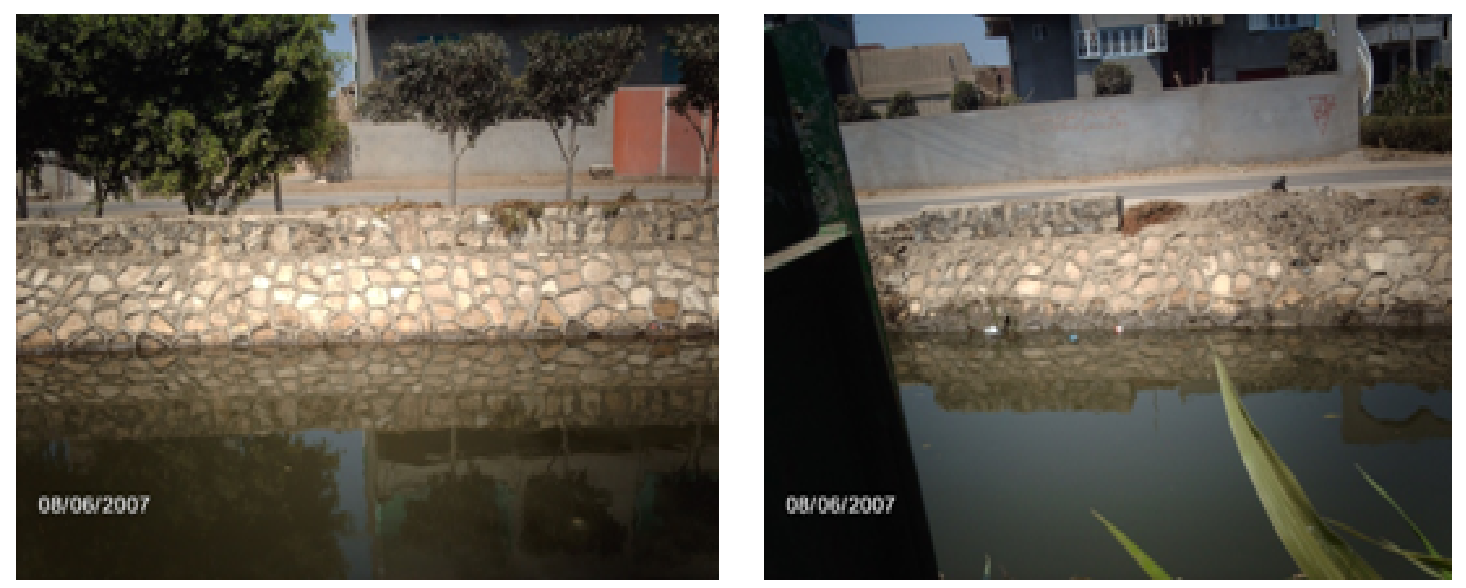

Photo 5: Pitching of damaged levees and dams of irrigation channels at Fatmia Drain 


\title{
ARABIC SUMMARY
}

\section{تقييم سلوك حفر الانفاق لاستاكوزا المياه العذبة (بروكمبراس كلاركى) في مصرف الفاطميه، الزقازيق، محافظه الثرقيه، مصرك.}

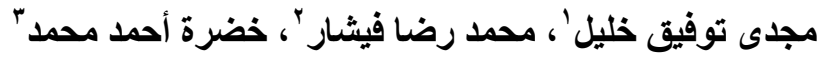

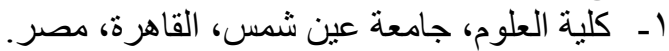

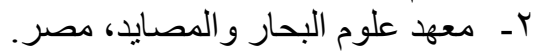

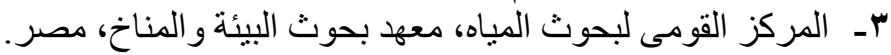

في او ائل الثمانينات غذت مياه النيل إستاكوز المستنقعات الحمراء ، و الذى تم استيراده من الو لايات

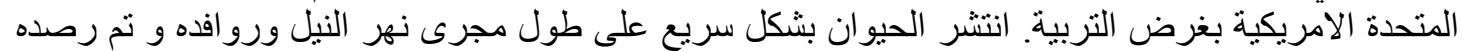

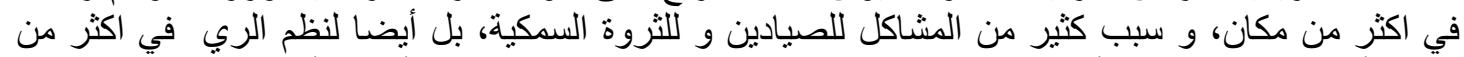

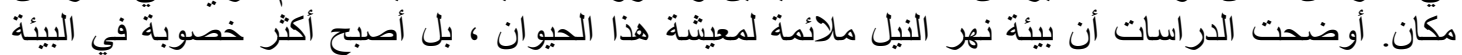

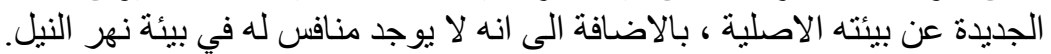

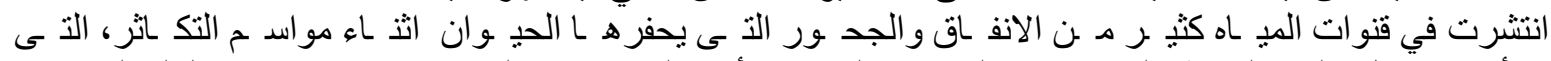

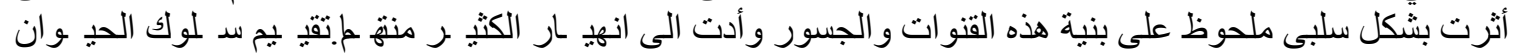

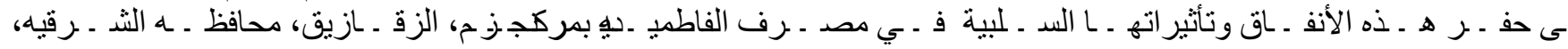

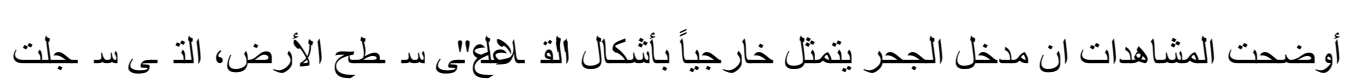

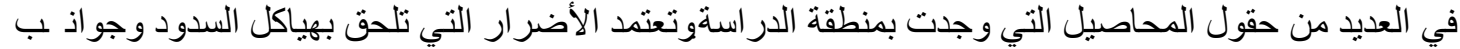

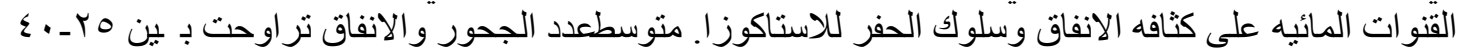

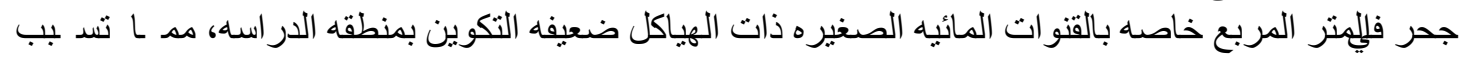

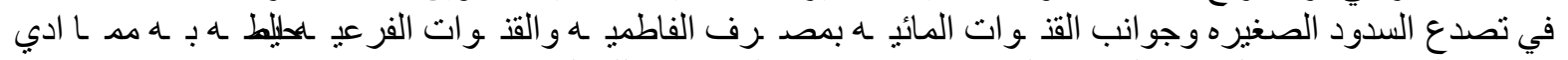
الى قيام وز اره المو ارد المائيه و الري بتدبيش جو النب العديد من تللك القنو ات والف واعاده انشاء سدودها. 